\title{
Antioxidant system is insufficient to prevent cell damages in Euterpe oleracea exposed to water deficit
}

\author{
Maria Antonia Machado Barbosa1, Allan Klynger da Silva Lobato ${ }^{1 *}$, Thaís Soares Pereira1, \\ Gélia Dinah Monteiro Viana', José Ricardo Santos Barbosa', Kelly Nayara Nascimento Coelho'
}

${ }^{1}$ Núcleo de Pesquisa Vegetal Básica e Aplicada, Universidade Federal Rural da Amazônia. Paragominas, Pará, Brazil

\section{A B S T R A C T}

\begin{abstract}
This study aimed to determine whether antioxidant enzymes are efficient to control the oxidative stress and consequent cell damages on leaves and roots in Euterpe oleracea plants exposed to water deficiency. This study was assembled under an experimental design completely randomized with two water conditions (water deficit and control) combined by four evaluation dates (0, 6, 12, and 18 days). Progressive water deficit promoted significant increases in electrolyte leakage and glutathione in both tissue types, and hydrogen peroxide and malondialdehyde were increased in the leaf. Antioxidant enzyme activities showed similar behaviours, with initial increases and subsequent decreases. Our results revealed that the cell damage observed in leaves and roots was induced by multiple effects related to overproduction of oxidant compounds, such as hydrogen peroxide, and by insufficient CAT, APX, and GPX activities in E. oleracea plants exposed to progressive water deficit.
\end{abstract}

Keywords: Antioxidant enzymes; Euterpe oleracea; Oxidative damage; Hydrogen peroxide; Water deficiency

\section{INTRODUCTION}

Water deficiency is a problem frequently found in field conditions, representing a limiting factor in areas with agricultural potential (Freitas et al., 2007). Interferences on growth plant also are detected on yield (Endres et al., 2010). Water supply is fundamental to keep the metabolic activity (Barbosa et al., 2014), nutrient absorption (Wang et al., 2011), gas exchange (Santos et al., 2009), and translocation of organic substances (Lobato et al., 2008).

The drought is an abiotic stress that induces the accumulation of hydrogen peroxide $\left(\mathrm{H}_{2} \mathrm{O}_{2}\right)$ and superoxide $\left(\mathrm{O}_{2}^{-}\right)$(Queiroz et al., 2002). These compounds promote the oxidation of membranes and cell damages (Mittler, 2002). In other hand, the antioxidant system uses key enzymes, such as catalase (CAT), ascorbate peroxidase (APX), and guaiacol peroxidase (GPX) to avoid the oxidative stress generated during inadequate conditions.

Palms, such as Euterpe oleracea, are one of the few plants of the monocot class that reach significant heights (Renninger and Phillips, 2011). Studies with palms frequently use the species Phoenix dactylifera and Elaeis guineensis as models (Suresh et al., 2012; Gribaa et al., 2013), being described significant cell damages after water deficit (Baslam et al., 2014). In other hand, biochemical approaches linked to antioxidant system and using E. oleracea plants can contribute to elucidate the cell damages verified in palm plants during water deficit.

This study aimed to determine whether antioxidant enzyme activities are sufficient to avoid the oxidative stress and consequent cell damage incurred by the leaves and roots of young Euterpe oleracea plants exposed to progressive water deficit.

\section{MATERIALS AND METHODS}

\section{Growth conditions}

The experiment was carried out in greenhouse under controlled temperature and humidity, with minimum, maximum, and median temperatures being $21^{\circ} \mathrm{C}, 34^{\circ} \mathrm{C}$, and $25^{\circ} \mathrm{C}$, respectively. Relative humidity during the period studded varied between $65 \%$ and $93 \%$.

\footnotetext{
${ }^{*}$ Corresponding author:

Allan Klynger da Silva Lobato, Rodovia PA 256, Paragominas, Pará, Brazil. Núcleo de Pesquisa Vegetal Básica e Aplicada, Universidade

Federal Rural da Amazônia. Phone: +55-91-983089845; Fax: +55-91-983089845, E- mail: allanllobato@yahoo.com.br

Received: 21 September 2016; Revised: 04 February 2017; Accepted: 07 February 2017; Published Online: 17 February 2017
} 


\section{Plants, containers, and substrate}

Seeds of Euterpe oleracea (Mart.) cv. BRS-Pará from EMBRAPA (Empresa Brasileira de Pesquisa Agropecuária/Brazil) were germinated in 8-L pots $(0.25 \mathrm{~m}$ in height and $0.20 \mathrm{~m}$ in diameter) equipped with holes for water drainage. The pots were filled with Plantmax ${ }^{\circledR}$ substrate, and the plants were irrigated daily with $1 \mathrm{~L}$ of distilled water. Seedlings received the following macro- and micronutrients from the nutritive solution: $8.75 \mathrm{mM}$ $\mathrm{KNO}_{3}, 7.5 \mathrm{mM} \mathrm{Ca}\left(\mathrm{NO}_{3}\right)_{2} \cdot 4 \mathrm{H}_{2} \mathrm{O}, 3.25 \mathrm{mM} \mathrm{NH}_{4} \mathrm{H}_{2} \mathrm{PO}_{4}$, $1.5 \mathrm{mM} \mathrm{MgSO}_{4} \cdot 7 \mathrm{H}_{2} \mathrm{O}, 62.50 \mu \mathrm{M} \mathrm{KCl}, 31.25 \mu \mathrm{M} \mathrm{H}_{3} \mathrm{BO}_{3}$, $2.50 \mu \mathrm{M} \mathrm{MnSO} \cdot \mathrm{H}_{2} \mathrm{O}, 2.50 \mu \mathrm{M} \mathrm{ZnSO} \cdot 7 \mathrm{H}_{2} \mathrm{O}, 0.63 \mu \mathrm{M}$ $\mathrm{CuSO}_{4} \cdot 5 \mathrm{H}_{2} \mathrm{O}, 0.63 \mu \mathrm{M} \mathrm{NaMoO} \cdot 5 \mathrm{H}_{2} \mathrm{O}$, and $250.0 \mu \mathrm{M}$ $\mathrm{NaEDTAFe} \cdot 3 \mathrm{H}_{2} \mathrm{O}$, being applied $0.4 \mathrm{~mL}$ per pot at regular intervals (every 30 days) until the $12^{\text {th }}$ month, being necessary this period to obtain young plants. Subsequently, one-year-old plants with similar aspects and sizes were selected to be used in this study.

\section{Experimental design and application of water deficit}

This study used a randomised design in factorial with two water conditions (water deficit and control) and four evaluation dates $(0,6,12$, and 18 days). The experiment was composed by five replicates and 40 experimental units, with one plant in each unit. Plants exposed to water deficit were submitted to 18 days under water restriction, while plants from control treatment were watered daily with distilled water. The leaf and root (middle region of the each tissue) were harvested and frozen in liquid nitrogen and stored at $-20^{\circ} \mathrm{C}$ for subsequent biochemical determinations.

\section{Leaf relative water content}

The leaf relative water content (LRWC) was evaluated using leaf discs with diameters of $10 \mathrm{~mm}$. From each plant, 40 discs were removed, and the LRWC was calculated using the formula $[(F M-D M) /(T M-D M)] \times 100$, as proposed by Slavick (1979). Here, FM represents fresh matter, TM represents turgid matter evaluated after $24 \mathrm{~h}$ and saturated in deionised water at $4^{\circ} \mathrm{C}$ in the dark, and $\mathrm{DM}$ represents dry matter determined after $48 \mathrm{~h}$ in an oven with forced air circulation at $80^{\circ} \mathrm{C}$.

\section{Electrolyte leakage}

Electrolyte leakage (EL) was measured according to the method described by Gong et al. (1998) with minor modifications. Leaf and root fresh $(200 \mathrm{mg})$ were cut into pieces with a length of $1 \mathrm{~cm}$ and were placed in containers containing $8 \mathrm{~mL}$ of distilled deionised water. The containers were incubated in a water bath at $40^{\circ} \mathrm{C}$ for $30 \mathrm{~min}$, and the initial electrical conductivity of the medium $\left(\mathrm{EC}_{1}\right)$ was measured. The samples were boiled at $95^{\circ} \mathrm{C}$ for $20 \mathrm{~min}$ to release the electrolytes. After the samples were cooled, the final electrical conductivity $\left(\mathrm{EC}_{2}\right)$ was measured (Gong et al., 1998). The percentage of electrolyte leakage was calculated using the formula $\mathrm{EL}(\%)=\mathrm{EC}_{1} / \mathrm{EC}_{2} \times 100$.

\section{Extraction of oxidant and antioxidant compounds}

Oxidant and antioxidant compounds $\left(\mathrm{H}_{2} \mathrm{O}_{2}, \mathrm{MDA}\right.$, and $\mathrm{GSH}$ ) were extracted from leaf and root tissues as described by Wu et al. (2006). Briefly, an extraction mixture was prepared by homogenising $500 \mathrm{mg}$ of fresh matter in $5 \mathrm{~mL}$ of $5 \%(\mathrm{w} / \mathrm{v})$ trichloroacetic acid. Subsequently, the samples were centrifuged at $15,000 \mathrm{x}$ g for $15 \mathrm{~min}$ at $3^{\circ} \mathrm{C}$, and the supernatant was collected.

\section{Hydrogen peroxide}

For $\mathrm{H}_{2} \mathrm{O}_{2}$ detection, $200 \mu \mathrm{L}$ of supernatant and $1,800 \mu \mathrm{L}$ of reaction mixture $(2.5 \mathrm{mM}$ potassium phosphate buffer [pH 7.0] and $500 \mathrm{mM}$ potassium iodide) were mixed, and the absorbance was measured at $390 \mathrm{~nm}$ (Velikova et al., 2000).

\section{Malondialdehyde}

MDA was determined by mixing $500 \mu \mathrm{L}$ of supernatant with $1,000 \mu \mathrm{L}$ of the reaction mixture, which contained $0.5 \%(\mathrm{w} / \mathrm{v})$ thiobarbituric acid in $20 \%$ trichloroacetic acid. The mixture was incubated in boiling water at $95^{\circ} \mathrm{C}$ for $20 \mathrm{~min}$, and the reaction was terminated by placing the reaction container in an ice bath. The samples were centrifuged at 10,000 $\mathrm{x}$ f for $10 \mathrm{~min}$, and the absorbance was measured at $532 \mathrm{~nm}$. The amount of non-specific absorption at $600 \mathrm{~nm}$ was subtracted from the absorbance data. The amount of MDA-TBA complex (red pigment) was calculated based on the method of Cakmak and Horst (1991) with minor modifications, using an extinction coefficient of $155 \mathrm{mM}^{-1} \mathrm{~cm}^{-1}$.

\section{Glutathione}

For GSH determination, $200 \mu \mathrm{L}$ of supernatant and $1,800 \mu \mathrm{L}$ of reaction mixture (containing $100 \mathrm{mM}$ phosphate buffer [ $\mathrm{pH} 7.6]$ and $0.60 \mathrm{mM}$ 2-nitrobenzoic acid) were combined, and the absorbance was measured at $412 \mathrm{~nm}$ (Wu et al., 2006).

Extraction of antioxidant enzymes and soluble proteins To determinate antioxidant enzymes (CAT, APX, and GPX) and soluble proteins were used leaf and root tissues (Badawi et al., 2004). The extraction mixture was prepared by homogenising $500 \mathrm{mg}$ of fresh matter in $5 \mathrm{~mL}$ of extraction mix, which contained $50 \mathrm{mM}$ phosphate buffer ( $\mathrm{pH}$ 7.6), $1.0 \mathrm{mM}$ ascorbate and $1.0 \mathrm{mM}$ EDTA. Subsequently, the samples were centrifuged at $14,000 \mathrm{xg}$ for $4 \mathrm{~min}$ at $3^{\circ} \mathrm{C}$, and the supernatant was collected. Quantification of the total soluble proteins was performed using the method described by Bradford (1976). The absorbance was measured at $595 \mathrm{~nm}$, and bovine albumin was used as a standard.

\section{Catalase}

For CAT determination, $200 \mu \mathrm{L}$ of supernatant and $1,800 \mu \mathrm{L}$ of reaction mixture (containing $50 \mathrm{mM}$ phosphate 
buffer [ $\mathrm{pH} 7.0]$ and $12.5 \mathrm{mM}$ hydrogen peroxide) were combined, and the absorbance was measured at $240 \mathrm{~nm}$ (Havir and McHale, 1987).

\section{Ascorbate peroxidase}

For APX determination, $1,800 \mu \mathrm{L}$ of reaction mixture containing $50 \mathrm{mM}$ phosphate buffer ( $\mathrm{pH} 7.0), 0.5 \mathrm{mM}$ ascorbate, $0.1 \mathrm{mM}$ EDTA, and $1.0 \mathrm{mM}$ hydrogen peroxide was mixed with $200 \mu \mathrm{L}$ of supernatant, and the absorbance was measured at $290 \mathrm{~nm}$ (Nakano and Asada, 1981).

\section{Guaiacol peroxidase}

The GPX determination, $1,780 \mu \mathrm{L}$ of reaction mixture (containing $50 \mathrm{mM}$ phosphate buffer $[\mathrm{pH} 7.0]$ and $0.05 \%$ guaiacol) was mixed with $200 \mu \mathrm{L}$ of supernatant. Subsequently, $20 \mu \mathrm{L}$ of $10 \mathrm{mM}$ hydrogen peroxide was added. The absorbance was then measured at $470 \mathrm{~nm}$ (Cakmak and Marschner, 1992).

\section{Data analysis}

The data obtained in this study were subjected to an analysis of variance, being significant differences detected using the $\mathrm{F}$ test at a probability level of 5\% (Steel et al., 2006). The standard deviations were obtained in all treatments. All statistical procedures were performed with ASSISTAT software.

\section{RESULTS}

Plants exposure to water deficit presented reduction in LRWC; however, significant effects were only observed on the $12^{\text {th }}$ and $18^{\text {th }}$ day after stress application (Table 1 ), if compared with control plants. The water deficit caused increase in EL in the leaf and root, which was significant in both tissues at the $12^{\text {th }}$ and $18^{\text {th }}$ days after water restriction. Compared to the control plants, the variations more intense in leaf and root were of 16\% (both) on the $18^{\text {th }}$ day (Table 1). Regarding $\mathrm{H}_{2} \mathrm{O}_{2}$, similar behaviours were observed in the leaf and root. On the $12^{\text {th }}$ day, the waterdeficient leaf showed a 39\% increase, compared with the control plants (Table 1), while in the root, the increase was not significant (17\% at the final evaluation date) (Table 1).

MDA was clearly increased in the leaf and root, but fluctuations were observed in root tissue. The leaf presented increases that were significant on the $12^{\text {th }}$ and $18^{\text {th }}$ day after water restriction (Table 2). Meanwhile, the root showed an initial decrease and subsequent significant increase during the course of the experiment (Table 2). The water deficit triggered similar behaviours in GSH concentrations in the leaf and root. When evaluated in the leaf, the greatest increase $(62 \%)$ was observed at the last time point (Table 2). In the root, large increases were
Table 1: Leaf relative water content, electrolyte leakage in leaf and root, and hydrogen peroxide in leaf and root of young Euterpe oleracea plants subjected to water deficit

\begin{tabular}{|c|c|c|}
\hline \multicolumn{3}{|c|}{ Leaf relative water content (\%) } \\
\hline \multirow[t]{2}{*}{ Time (days) } & \multicolumn{2}{|c|}{ Water condition } \\
\hline & Control & Water deficit \\
\hline 0 & $80.7 \pm 4.6 a$ & $82.7 \pm 4.1 \mathrm{a}$ \\
\hline 6 & $78.2 \pm 6.1 \mathrm{a}$ & $74.9 \pm 3.8 \mathrm{a}$ \\
\hline 12 & $75.7 \pm 4.0 \mathrm{a}$ & $55.7 \pm 5.2 b$ \\
\hline 18 & $77.3 \pm 7.0 \mathrm{a}$ & $48.5 \pm 2.3 b$ \\
\hline \multicolumn{3}{|c|}{ Electrolyte leakage in leaf (\%) } \\
\hline \multirow[t]{2}{*}{ Time (days) } & \multicolumn{2}{|c|}{ Water condition } \\
\hline & Control & Water deficit \\
\hline 0 & $83.5 \pm 5.6 a$ & $83.8 \pm 5.2 a$ \\
\hline 6 & $82.4 \pm 5.4 a$ & $90.5 \pm 3.1 \mathrm{a}$ \\
\hline 12 & $82.6 \pm 3.8 \mathrm{a}$ & $94.2 \pm 4.5 b$ \\
\hline 18 & $81.8 \pm 4.5 \mathrm{a}$ & $95.1 \pm 2.0 \mathrm{~b}$ \\
\hline \multicolumn{3}{|c|}{ Electrolyte leakage in root (\%) } \\
\hline \multirow[t]{2}{*}{ Time (days) } & \multicolumn{2}{|c|}{ Water condition } \\
\hline & Control & Water deficit \\
\hline 0 & $84.0 \pm 2.3 a$ & $84.1 \pm 2.1 \mathrm{a}$ \\
\hline 6 & $84.1 \pm 3.4 a$ & $90.3 \pm 3.4 a$ \\
\hline 12 & $84.3 \pm 3.3 a$ & $95.3 \pm 4.1 b$ \\
\hline 18 & $82.3 \pm 1.9 a$ & $95.6 \pm 1.2 b$ \\
\hline \multicolumn{3}{|c|}{ Hydrogen peroxide in leaf $\left(\mu \mathrm{mol} \mathrm{g}^{-1} \mathrm{FM}\right)$} \\
\hline \multirow[t]{2}{*}{ Time (days) } & \multicolumn{2}{|c|}{ Water condition } \\
\hline & Control & Water deficit \\
\hline 0 & $5.43 \pm 0.51 a$ & $5.55 \pm 0.42 a$ \\
\hline 6 & $5.26 \pm 0.30 \mathrm{a}$ & $5.37 \pm 0.40 \mathrm{a}$ \\
\hline 12 & $5.51 \pm 0.47 a$ & $7.66 \pm 0.57 b$ \\
\hline 18 & $5.70 \pm 0.22 \mathrm{a}$ & $7.72 \pm 0.33 b$ \\
\hline \multicolumn{3}{|c|}{ Hydrogen peroxide in root ( $\left.\mu \mathrm{mol} \mathrm{g}^{-1} \mathrm{FM}\right)$} \\
\hline \multirow[t]{2}{*}{ Time (days) } & \multicolumn{2}{|c|}{ Water condition } \\
\hline & Control & Water deficit \\
\hline 0 & $1.91 \pm 0.18 \mathrm{a}$ & $1.95 \pm 0.13 a$ \\
\hline 6 & $1.76 \pm 0.14 a$ & $1.86 \pm 0.10 \mathrm{a}$ \\
\hline 12 & $1.86 \pm 0.12 a$ & $1.96 \pm 0.25 a$ \\
\hline 18 & $1.72 \pm 0.13 a$ & $2.02 \pm 0.23 a$ \\
\hline
\end{tabular}

Lines with different letters indicate significant differences at $\mathrm{F}$ test $(P<0.05)$ to each time values described corresponding to means from five repetitions and standard errors

detected, with an increase of $112 \%$ after 18 days of water deficit (Table 2).

The CAT activity exhibited a similar tendency in both tissues evaluated, with an increase and subsequent decrease. In leaves, the increase was significant only on the $6^{\text {th }}$ day, with a variation of $145 \%$; however, the level of this enzyme was decreased at other times (Fig. 1 A). Additionally, significant increases were noted in the root at 6 and 12 days, with the highest increase being 309\%; however, a reduction was observed at the final time point (Fig. 1 B). Water restriction provoked an initial increase in APX and a subsequent reduction in both the leaf and root (Fig. $1 \mathrm{C}$ and D); significant peaks were observed at the $12^{\text {th }}$ and $6^{\text {th }}$ day, respectively, with reductions observed 


\begin{tabular}{|c|c|c|}
\hline \multicolumn{3}{|c|}{ 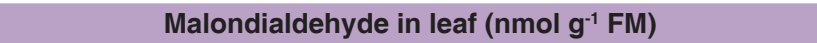 } \\
\hline \multirow[t]{2}{*}{ Time (days) } & \multicolumn{2}{|c|}{ Water condition } \\
\hline & Control & Water defici \\
\hline 0 & $8.52 \pm 0.72 a$ & $8.66 \pm 0.61 a$ \\
\hline 6 & $8.31 \pm 0.62 a$ & $10.02 \pm 0.82 b$ \\
\hline 12 & $8.66 \pm 0.75 a$ & $11.15 \pm 0.85 b$ \\
\hline 18 & $8.58 \pm 0.81 a$ & $11.56 \pm 0.72 b$ \\
\hline \multicolumn{3}{|c|}{ Malondialdehyde in root (nmol g-1 FM) } \\
\hline \multirow[t]{2}{*}{ Time (days) } & \multicolumn{2}{|c|}{ Water condition } \\
\hline & Control & Water defici \\
\hline 0 & $3.23 \pm 0.23 a$ & $3.21 \pm 0.25 a$ \\
\hline 6 & $3.26 \pm 0.31 a$ & $2.85 \pm 0.22 a$ \\
\hline 12 & $3.02 \pm 0.22 a$ & $3.56 \pm 0.25 b$ \\
\hline 18 & $3.03 \pm 0.24 a$ & $3.68 \pm 0.26 b$ \\
\hline \multicolumn{3}{|c|}{ Total glutathione in leaf $\left(\mu \mathrm{mol} \mathrm{g}^{-1} \mathrm{FM}\right)$} \\
\hline \multirow[t]{2}{*}{ Time (days) } & \multicolumn{2}{|c|}{ Water condition } \\
\hline & Control & Water deficit \\
\hline 0 & $4.32 \pm 0.36 a$ & $4.36 \pm 0.31 a$ \\
\hline 6 & $4.13 \pm 0.25 a$ & $4.83 \pm 0.24 b$ \\
\hline 12 & $4.34 \pm 0.29 a$ & $5.12 \pm 0.27 \mathrm{~b}$ \\
\hline 18 & $4.17 \pm 0.31 a$ & $6.78 \pm 0.52 b$ \\
\hline \multicolumn{3}{|c|}{ Total glutathione in root $\left(\mu \mathrm{mol} \mathrm{g}^{-1} \mathrm{FM}\right)$} \\
\hline \multirow[t]{2}{*}{ Time (days) } & \multicolumn{2}{|c|}{ Water condition } \\
\hline & Control & Water deficit \\
\hline 0 & $0.41 \pm 0.02 a$ & $0.43 \pm 0.03 a$ \\
\hline 6 & $0.42 \pm 0.03 a$ & $0.47 \pm 0.03 a$ \\
\hline 12 & $0.41 \pm 0.05 a$ & $0.67 \pm 0.05 b$ \\
\hline 18 & $0.40 \pm 0.04 a$ & $0.85 \pm 0.07 b$ \\
\hline
\end{tabular}

Lines with different letters indicate significant differences at $\mathrm{F}$ test $(P<0.05)$ to each time values described corresponding to means from five repetitions and standard errors

at other times. Water deficits induced increases in GPX in leaf and root tissues; the increases were similar in the leaf and root, with $97 \%$ and $130 \%$ increases observed (Fig. $1 \mathrm{E}$ and F), respectively, at 12 days of water deficit.

\section{DISCUSSION}

Water deficiency promoted decrease in LRWC, being explained by the lower water quantity absorbed by the plant via substrate and losses by transpiration, causing wilted leaves. The increases in EL in the leaf and root induced after water deficit can be explained due to the higher membrane permeability, which causes damage to membranes and cellular organelles that is frequently irreversible, with a consequent increase in EL (Slama et al., 2011). Gonçalves et al. (2011) evaluating the effects of the water deficit by eight consecutive days on Jatropha curcas plants reported non-significant modifications in EL, suggesting that E. oleracea is more sensitive that J. curcas.

The water deficit caused an increase in $\mathrm{H}_{2} \mathrm{O}_{2}$ in leaf and root tissues, which was most likely linked to higher superoxide dismutase (SOD) activity and a decrease in catalase activity. These changes are more intense when plants are exposed to water deficiency. $\mathrm{H}_{2} \mathrm{O}_{2}$ is toxic, and it is overproduced in plant cells exposed to abiotic stress, such as water deficit (Chang et al., 2012). He et al. (2012) described highest $\mathrm{H}_{2} \mathrm{O}_{2}$ accumulation in leaf, following by stem and root in Solanum tuberosum plants exposed to water limitation. The increase in MDA in both tissues was caused by the actions of reactive oxygen species (ROS), such as $\mathrm{H}_{2} \mathrm{O}_{2}$ and $\mathrm{O}_{2}^{-}$, which areproduced during stress (Arcoverde et al., 2011). ROS also promote lipid peroxidation due to membrane denaturation and consequent increases in MDA levels. Sofo et al. (2004) reported also significant increases in leaf and root tissues of Olea europaea plants subjected to controlled water deficit for 20 days. In relation to GSH, increases in leaf and root were observed after water deficit, being this fact explained as a consequence induced by oxidative stress; additionally, it can be utilised as an indicator of water deficit (Gill and Tuteja, 2010).

The water restriction caused an initial increase and a subsequent decrease in CAT activity in the leaf and root. The increase in the activity of this enzyme was induced by $\mathrm{H}_{2} \mathrm{O}_{2}$ accumulation, and the reduction was related to an insufficient capacity to remove oxidant compounds produced during water deficit. This enzyme is involved in antioxidant protection and maintenance of membrane integrity (Carvalho et al., 2012). Marron et al. (2006) showed an increase in CAT activity in leaves of Populus deltoides clones. Slight peaks in the APX enzyme were observed with a subsequent decrease in its activity in both tissues. The increases are likely associated with the formation of reactive oxygen species (ROS) during water limitation, while the decrease most likely occurred due to limited ascorbate supply. APX is a key enzyme in the ascorbateglutathione cycle, in which it attenuates the oxidative stress generated under inadequate conditions (Shvaleva et al., 2006). An increase in APX activity was also found by Pérez-Clemente et al. (2012), who studied Citrange carrizo plants under water stress. The limited increase in GPX activity can be explained by the fact that water deficit promotes the formation of free radicals, such as $\mathrm{O}_{2}^{-}$, and the consequent accumulation of oxidative compounds because this enzyme catalyses the reaction that uses $\mathrm{H}_{2} \mathrm{O}_{2}$ and $\mathrm{GSH}$ as substrates to produce oxidised glutathione (GSSG) and water $\left(\mathrm{H}_{2} \mathrm{O}\right)$, exerting a fundamental role in the antioxidant machinery (Sayfzadeh and Rashidi, 2010).

Progressive water deficit promoted significant increases in electrolyte leakage and glutathione in both leaf and root tissues, and hydrogen peroxide and malondialdehyde were increased in the leaf. The activities of antioxidant 


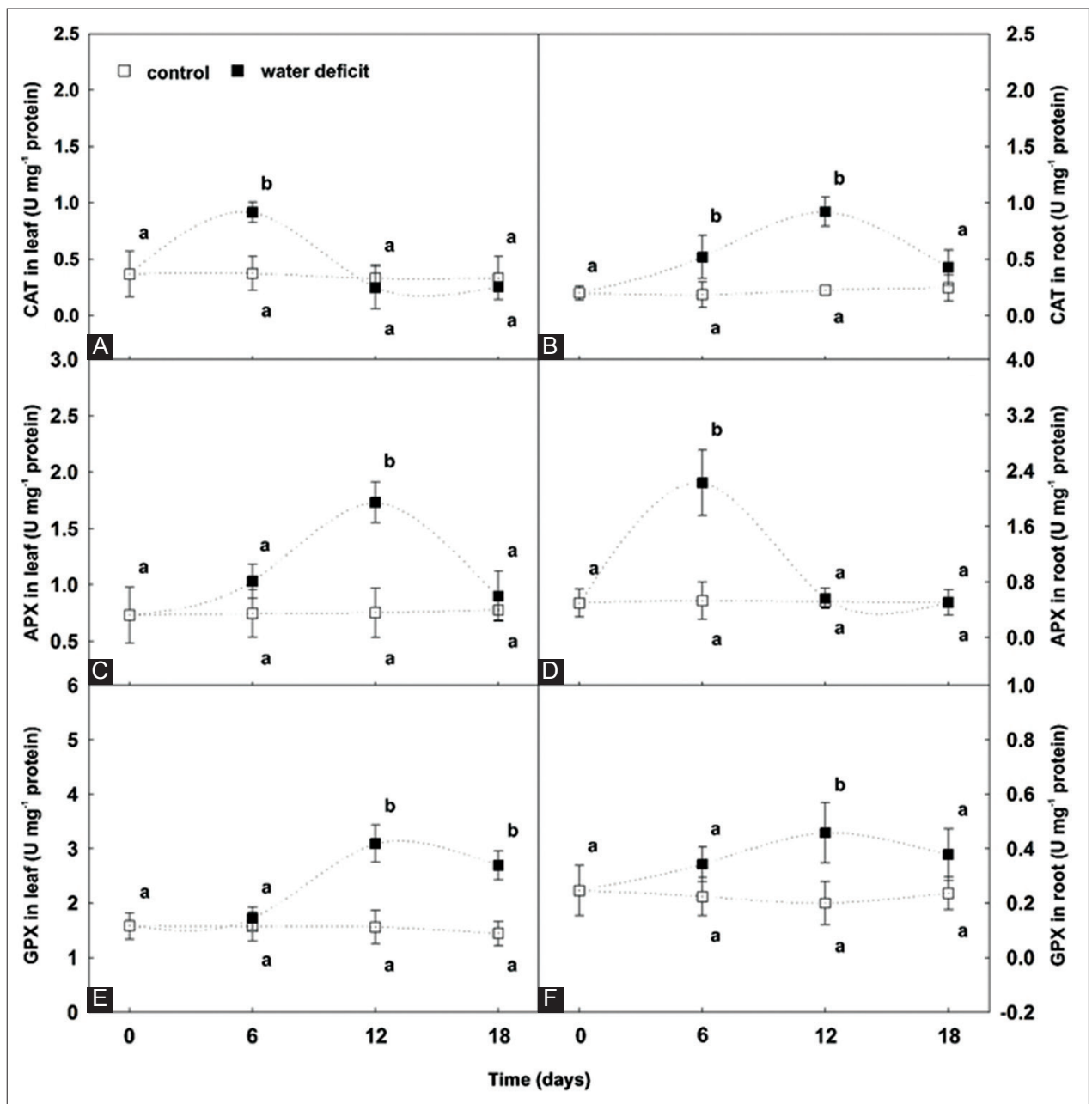

Fig 1. Catalase activities in leaf and root $(A-B)$, ascorbate peroxidase activities in leaf and root $(C-D)$, and guaiacol peroxidase activities in leaf and root $(E-F)$ in young Euterpe oleracea plants subjected to water deficit. Different letters indicate significant differences at $F$ test $(P<0.05)$ to each time. Squares represent the mean values of 5 repetitions, and bars represent the standard errors.

enzymes showed similar trends, with initial increases and subsequent decreases. Our results revealed that the cell damage observed in leaves and roots was induced by multiple effects related to the overproduction of oxidant compounds, such as hydrogen peroxide, as well as the insufficient activity of antioxidant enzymes (CAT, APX, and GPX) in young Euterpe oleracea plants exposed to progressive water deficit.

\section{ACKNOWLEDGEMENTS}

This research had financial supports from Conselho Nacional de Desenvolvimento Científico e Tecnológico (CNPq/Brazil) and Universidade Federal Rural da Amazônia (UFRA/Brazil) to Lobato AKS, and Barbosa MAM, Viana GDM, Barbosa JRS, Coelho KNN, and Pereira TS were supported by undergraduate scholarships also from Conselho Nacional de Desenvolvimento Científico e Tecnológico (CNPq/Brazil).

\section{Author contributions}

Lobato A.K.S. was the advisor of this project and planned all phases of this research. Barbosa M.A.M., Pereira T.S., Viana G.D.M., Barbosa J.R.S. and Coelho K. $\mathrm{N}$. N. conducted the experiment in the greenhouse and performed physiological, biochemical and morphological determinations, as well as interpreted the results and wrote the manuscript.

\section{REFERENCES}

Arcoverde, G. B., B. M. Rodrigues, M. F. Pompelli and M. G. Santos. 2011. Water relations and some aspects of leaf metabolism of Jatropha curcas young plants under two water deficit levels and recovery. Braz. J. Plant Physiol. 23: 123-130.

Badawi, G. H., Y. Yamauchi, E. Shimada, R. Sasaki, N. Kawano, K. Tanaka and K. Tanaka. 2004. Enhanced tolerance to salt stress and water déficit by overspressing superoxide dismutase in tobacco (Nicotiana tabacum) chloroplasts. Plant Sci. 166: 919-928. 
Barbosa, M. A. M., A. K. S. Lobato, T. S. Pereira, G. D. M. Viana, J. R. S. Barbosa, K. N. N. Coelho, L. S. Sampaio, B. G. Santos Filho and J. A. G. Silveira. 2014. Photosynthesis-involvement in modulation of ascorbate and glutathione in Euterpe oleracea plants exposed to drought. Not. Bot. Horti. Agrobot. 42: 119-127.

Baslam, M., A. Qaddoury and N. Goicoechea. 2014. Role of native and exotic mycorrhizal symbiosis to develop morphological, physiological and biochemical responses coping with water drought of date palm, Phoenix dactylifera. Trees. 28: 161-172.

Bradford, M. M. 1976. A rapid and sensitive method for the quantification of microgram quantities of protein utilizing the principle of protein-dye binding. Anal. Biochem. 72: 248-254.

Cakmak, I. and W. J. Horst. 1991. Effect of aluminium on lipid peroxidation, superoxide, dismutase, catalase, and peroxidase activities in root tips of soybean (Glycine max). Physiol. Plant. 83: 463-468.

Cakmak, I. and H. Marschner. 1992. Magnesium deficiency and high light intensity enhance activities of superoxide dismutase, ascorbate peroxidase, and glutathione reductase in bean leaves. Plant Physiol. 98: 1222-1227.

Carvalho, M. H. C. 2008. Drought stress and reactive oxygen species. Plant Signal Behav. 3: 156-165.

Carvalho, J. S. B., J. D. L. Martins and K. A. Moreira. 2012. Physiologial responses of Hyptis pectinata (L.) Poit. Under water stress. Rev. Biol. Cienc. Terra. 12: 20-28.

Chang, M., L. Liao, J. Lin, Z. Liu, Y. Hsu and T. Lee. 2012. Modulation of antioxidant defense system and NADPH oxidase in Pluchea indica leaves by water deficit stress. Bot. Stud. 53: 45-54.

Endres, L., J. L. Souza, I. Teodoro, P. M. G. Marroquim, C. M. Santos and J. E. D. Brito. 2010. Gas exchange alteration caused by water déficit during the bean reproductive stage. Ver. Bras. Eng. Agric. Ambient. 14: 11-16.

Freitas, J. M. N., K. S. Carvalho, A. K. S. Lobato, D. S. Castro, P. S. P. Maia, C. F. Oliveira Neto and R. C. L. Costa. 2007. Nitrate reductase activity, relative water content and total soluble chlorophyll contents in leaves of Açai (Euterpe edulis Mart.) Submitted to drought and flooding. Braz. J. Biosci. 5: 924-926.

Gill, S. S. and N. Tuteja. 2010. Reactive oxygen species and antioxidant machinery in abiotic stress tolerance in crop plants. Plant Physiol. Biochem. 48: 909-930.

Gonçalves, W. G., A. L. Costa, D. P. Lima, A. A. Silva and C. A. Megguer. 2011. Membrane permeabilty and relative water content in physic nuts submitted to fast water deficit. Glob. Sci. Technol. 4: 131-139.

Gong, M., Y. J. Li and S. Z. Chen. 1998. Abscisic acid-induced thermotolerance in maize seedilings is mediated by calcium and associated with antioxidant systems. J. Plant Physiol. 153: 488-496.

Gribaa, A., F. Dardelle, A. Lehner, C. Rihouey, C. Burel, A. Ferchichi, A. Driouich and J. C. Mollet. 2013. Effect of water deficit on the cell wall of the date palm (Phoenix dactylifera 'Deglet nour', Arecales) fruit during development. Plant Cell Environ. 36: 1056-1070.

Havir, E. A. and N. A. McHale. 1987. Biochemical and developmental characterization of multiple forms of catalase in tabacco leaves. Plant Physiol. 84: 450-455.

$\mathrm{He}, \mathrm{X}$., D. Ma and M. Meng. 2012. Exogenous nitric oxide enhances root activity, decreases $\mathrm{H}_{2} \mathrm{O}_{2}$ accumulation by increasing activities of CAT and GR in root of potato cv. Desiree under water-stress. Adv. J. Food Sci. Technol. 5: 148-152.

Hoagland, D. R. and D. I. Arnon. 1950. The water culture method for growing plants without soil. California Agricultural Experiment Station, $1^{\text {st }}$ ed. California Publisher, San Francisco, USA.
Lobato, A. K. S., C. F. Oliveira Neto, B. G. Santos Filho, R. C. L. Costa, F. J. R. Cruz, H. K. B. Neves and M. J. S. Lopes. 2008. Physiological and biochemical behavior in soybean (Glycine max cv. Sambaiba) plants under water deficit. Aust. J. Crop Sci. 2: 25-32.

Marron, N., S. Maury, C. Rinaldi and F. Brignolas. 2006. Impact of drought and leaf development stage on enzymatic antioxidant system of two Populus deltoides $\times$ nigra clones. Ann. For. Sci. 63: 323-327.

Nakano, Y. and K. Asada. 1981. Hydrogen peroxide is scavenged by ascorbate specific peroxidase in spinach chloroplasts. Plant Cell Physiol. 22: 867-880.

Perez-Clemente, R. M., A. Montoliu, S. I. Zandalinas, C. Ollas and A. Gómez-Cadenas. 2012. Carrizo citrange plants do not require the presence of roots to modulate the response to osmotic stress. Sci. Word J. 12: 01-13.

Queiroz, C. G. S., Q. S. Garcia and J. P. Lemos Filho. 2002. Photosynthetic activity and membrane lipid peroxidation in plants mastic-the-wilderness under water stress and after rehydration. Braz. J. Plant Physiol. 14: 59-63.

Renninger, H. J. and N. Phillips. 2011. Hydraulic properties of fronds from palms of varying height and habitat. Oecologia. 167: 925-935

Santos, M. G., R. V. Ribeiro, E. C. Machado and C. Pimentel. 2009. Photosynthetic parameters and leaf water potencial of live common bean genotypes under mild water deficit. Biol. Plant. 53: 229-236.

Sayfzadeh, S. and M. Rashidi. 2010. Effect of drought stress on antioxidant enzyme activities and root yield of sugar beet (Beta vulgaris). Am. Euras. J. Agric. Environ. Sci. 9: 223-230.

Shvaleva, A. L., C. E. Silva, E. Breia, L. Jouve, J. F. Hausman, M. H. Almeida, J. P. Maroco, M. L. Rodrigues, J. S. Pereira and M. M. Chaves. 2005. Metabolic responses to water deficit in two Eucalyptus globulus clones with contrasting drought sensitivity. Tree Physiol. 26: 239-248.

Slama, I., S. Tayachi, A. Jdey, A. Rouached and C. Abdelly. 2011. Differential response to water deficit stress in alfalfa (Medicago sativa) cultivars: Growth, water relations, osmolyte accumulation and lipid peroxidation. Afr. J. Biotechnol. 10: 16250-16259.

Slavick, B. 1979. Methods of Studying Plant Water Relations, $1^{\text {st }}$ ed. Springer-Verlag, New York, USA.

Sofo, A., B. Dichioa, C. Xiloyannisa and A. Masiab. 2004. Lipoxygenase activity and proline accumulation in leaves and roots of olive trees in response to drought stress. Physiol. Plant. 121: 58-65.

Steel, R. G. D., J. H. Torrie and D. A. Dickey. 2006. Principles and Procedures of Statistics: A Biometrical Approach, $1^{\text {st }}$ ed. Academic Internet Publishers, Moorpark, USA.

Suresh, K., C. Nagamani, D. L. Kantha and M. K. Kumar. 2012. Changes in photosynthetic activity in five common hybrids of oil palm (Elaeis guineensis Jacq.) seedlings under water deficit. Photosynthetica. 50: 549-556.

Velikova, V., I. Yordanov and A. Edreva. 2000. Oxidative stress and some antioxidant system in acid rain treated bean plants: Protective role of exogenous polyamines. Plant Sci. 151: 59-66.

Wang, C. Q., T. L. Liu and H. J. Xu. 2011. Ascorbate - Glutathione metabolism during PEG-Induced water deficit in Trifolium repens. Russ. J. Plant Physiol. 58: 597-602.

Wu, Q. S., R. X. Xia and Y. N. Zou. 2006. Reactive oxygen metabolism in mycorrhizal and non-mycorrhizal citrus (Poncirus trifoliate) seedlings subjected to water stress. J. Plant Physiol. 163: $1101-1110$. 